\title{
Regional concentration of higher education
}

\author{
Peter Čajka ${ }^{1 *}$, Anna Rybakova $^{2}$, Liudmila Alieva ${ }^{3}$, and Aleksandra Shcheglova ${ }^{4}$ \\ ${ }^{1}$ Matej Bel University, Department of International Relations and Diplomacy, Faculty of Political \\ Science and International Relations, Kuzmányho 1, 97401 Banská Bystrica, Slovak Republic \\ ${ }^{2}$ Moscow Institute of Physics and Technology, 1A/1 Kerchenskaya str., Moscow, 117303, Russian \\ Federation \\ ${ }^{3}$ Pskov State University, 2 Lenin Square, Pskov 180000, Russian Federation \\ ${ }^{4}$ Russian State Social University, 4/1Wilhelm Pik str, Moscow129226 Russian Federation
}

\begin{abstract}
This research article focuses on the regional concentration of higher education. The purpose of the research is to examine the effects of this concentration and to devise some possible outcomes and implications for the regional economic growth and development. We discuss the endogeneity of higher education and evaluate the differences such as the official demographic projections or the growth-related factors, including student numbers predicted by official statisticians. Our article contributes to ongoing research on the role of higher education in promoting regional economic development and emerging inequalities in the regions around the world. In addition, it focuses on the existence of the multiple channels of activity through which tertiary education institutions (TEIs) benefit their regional economies. In addition, the paper tackles the issue of regional concentration of TEIs within and across regions and clearly demonstrates how the geography of higher education has evolved and developed in the recent years.
\end{abstract}

Keywords: higher education, regional concentration, demographic changes.

\section{Introduction}

Regional concentration of higher education surely has a point and some relevant implications. The strong concentration of regional universities in any region can surely become an important asset in promoting economic recovery and growth [1]. These are numerous and well-known government flagships of public research such as the universities and community colleges that offer a full range of four-year degrees. The universities conduct research on labour supply and demand, labour development and best practices. They mitigate the effects of economic downturns and serve as an important source of job growth during recovery periods. Many countries boast a significant inventory of regional public universities, which are important assets for promoting economic recovery, and significant economic assets for smaller rural and larger urban communities [2]. Ensuring the vitality of these clusters and improving the environment for new and related clusters is crucial for regional economic development [3].

\footnotetext{
*Corresponding author: peter.cajka@umb.sk
} 
There is no question that higher education will play an important and growing role in the regional economy of any nation's future, and colleges and universities are closely linked to the health of their communities and regions [4]. Higher education institutions must take the lead in ensuring public-private cooperation to develop and implement regional economic plans that address weaknesses in the general business environment and constraints on cluster development. In order to best manage their role and use the economy surrounding it to improve their own competitive position, colleges and universities need to understand the composition of regional economies and what universities can contribute [5]. Tertiary education is crucial to improving primary and secondary education, as tertiary institutions prepare teachers, administrators, executives, and other education professionals to create policies and personnel schools for young children [6].

Nowadays, the surge in young people interested in secondary and post-secondary education, increasing urbanization in developing countries, and the rise of new middleincome countries seeking to increase their economic competitiveness require a comprehensive and holistic strategy focused on the effective implementation of the entire system [7]. Achieving these objectives requires defining governance, management and strategic leadership in higher education and other areas of public management [8].

Our research contributes to ongoing research on the role of higher education in promoting regional economic development and emerging inequalities in the regions around the world. The regional distribution of tertiary education shows how the recent growth in the sector has contributed to promoting a more equitable geographical distribution of growth and consolidating existing centres of excellence. In the next section, there are the multiple channels of activity through which tertiary education institutions (TEIs) benefit their host countries and regional economies. As a result, governments have taken explicit measures to decentralize the provision of TEs in order to achieve regional policy objectives. There are the long-term effects of universities and colleges on regional growth and knowledge spill-over effects. In addition, there is a long tradition in regional economics to examine the impact of TEI on student spending [9]. Researchers model the relationship between higher education and local economic growth. The presence of colleges and universities is believed to lead to greater concentration of qualified workers in one location, and the above model provides indirect conceptual support for growth-enhancing effects at universities [10,11]. On the basis of this model, institutions that offer programmes in areas with a stronger tendency towards industrial activity are associated with a greater impact on economic growth. Universities and colleges are producers of skilled labour, and areas near them tend to have a higher concentration of skilled labour. There are a large number of empirical studies linking regional economic development to higher education, and many focuses on the spending effects of universities $[12,13]$. For example, in the United States the four-year institutions that emphasize the liberal arts are known as "halls of residence", because they have lower enrolment and lower student-teacher ratios than universities. Some of them also offers experimental curricula [14].

In general, for-profit higher education, also known as for-profit colleges or proprietary education, refers to higher education institutions that operate as private, for-profit enterprises. The term university education generally refers to polytechnic or university degrees. To cope with the explosive growth of K-12 education, the states established a network of colleges of teachers that began in Massachusetts in the 1830s. In the 1950s, teacher colleges became state colleges and public universities with broader curricula [15]. However, the COVID-19 pandemic, combined with stagnant population growth, a healthy economy and higher tuition, has led to a decrease in enrolment at public universities.

Researchers often find a robust positive correlation between the regions with the initial share of workers with university degrees changing over time. The local labour markets with a higher initial share have seen a greater increase in the share of university graduates, and the 
migration behaviour of university graduates reinforces this pattern of skills divergence between regions [16]. The largest and most populous regions have the largest net migration flows of young university graduates, while the smallest regions have the second largest net migration flows. This does not mean that the human capital effect and the location effect are a zero-sum game in which one region's success draws resources from another [17]. The inequal distribution of human capital reinforces mobility patterns of university graduates and the regional sorting is evident by school grades and parental background. This is due to the fact that we have seen different patterns of qualification between regions and countries over the last three decades.

\section{Economic impacts of tertiary education on regional development}

The way knowledge is disseminated implies that universities influence not only their own location, but also neighbouring areas. As self-producers of knowledge and human capital, they accelerate capital accumulation and technological change in the regions and have a lasting impact on economic growth. For example, universities in Silicon Valley can influence growth by fostering innovation in their regions $[18,19]$. With regard to that, Valero and van Reenen [20] examined the impact of university growth on regional growth. They showed that university activities, in particular knowledge-based activities such as teaching and basic research, have a significant positive impact on a range of measures of regional economic progress. There is indeed a greater impact of modern universities on local and regional development.

It turns out that the expansion of higher education during this period was not only a product of wealth, but also helped to stimulate economic growth around the world. These results are consistent with the conclusions of contextual work linking universities and their spending to local businesses and regional economic outcome [21]. The economic impact of higher education is important for regional development, but even with participation rates rising, itis unclear how regions have benefited.

One of the best examples can be analysis of the regional distribution of higher education in Europe with the aim of finding out whether the recent growth of the sector has contributed to promoting a more equitable geographical distribution of this growth or to establishing existing centres of excellence. A study of the panel of European regions can show how the geography of higher education developed in the recent years [22]. There is no question that higher education will play an important and growing role in the regional economy in our nation's future, as colleges and universities are closely linked to the health of their communities and regions. Higher education institutions must understand the composition of regional economies to which they contribute in order to manage their role best and to utilize the surrounding economy to improve their own competitive position [23]. Higher education institutions must also play a leading role in ensuring public-private cooperation to develop and implement regional economic plans that address weaknesses in the general business environment and constraints on cluster development [24]. To achieve these objectives, governance, management and strategic governance of higher education, as in other areas of public management, must be defined. Tertiary education is crucial to improving primary and secondary education, as tertiary institutions prepare teachers, administrators, executives, and other education professionals to create policies and personnel schools for young children. Public and private providers must be able to fulfil the comprehensive functions and requirements of the tertiary education sector outlined in this section. For example, the policymakers and the governments should ensure that appropriate laws and funding mechanisms are in place and that its role is complemented by institutional stakeholders (public and private), buffer points (regulatory and quality assurance agencies, think tanks, data 
warehouses) and key actors (rectors' councils, student organisations, chambers and industry associations). The long-term effects of universities and colleges on regional growth and knowledge spill-over effects are therefore evident [25].

It is generally assumed that the presence of colleges and universities leads to a greater concentration of qualified workers in one location, and the above model provides indirect conceptual support for growth-enhancing effects at universities. Robust results for the impact on neighbouring counties provide clear evidence of the transmission of knowledge from universities (such as the research universities in the United States that have been increasingly involved in economic development since the mid-1980s). Colleges and universities are important economic drivers for their surrounding communities, and their potential impact on the regional economy as a whole is increasing [26]. Interest in measuring the impact of higher education on regional economies has grown accordingly.

\section{Higher education and regional economic development}

Many regions worldwide are undergoing demographic and industrial changes that will affect their economic development in the context of education. The younger and more predictable technological changes in the industry, the more jobs that require higher education, and the more need for continuous training. Higher education institutions must take the lead in ensuring public-private cooperation to develop and implement regional economic plans that address weaknesses in the general business environment and constraints on cluster development [27]. Institutions can strengthen their regional economies through a variety of targeted initiatives, ranging from creating jobs, developing real estate, advising start-ups, conducting basic research, and promoting local industries. The role of higher education in economic development is crucial in raising the level of education in the region, but this will not lead to economic growth if education is not coordinated in such a way that it meets the current and potential needs of industry and is accessible to all potential workers. The role of higher education includes economic development as part of its core mission. There is no question that higher education plays an important and growing role in the regional economy of our country's future, as colleges and universities are closely connected to the health of their communities and regions [28].

In order to maximise their role in exploiting the surrounding economy to improve their own competitive position, higher education institutions need to understand the composition of the regional economies to which they contribute. In recent years, universities and colleges have been seen as key players in industrial renewal and regional economic growth owing to their assumed impact on spatial knowledge production, innovation and social change [29]. In the last decade, efforts to promote academic entrepreneurship, defined as initiatives aimed at generating knowledge spill-over effects from university research that lead to university spinoffs and the creation of new venture capitalists, have been highlighted as an important catalyst for innovation and economic growth.

The role of universities in economic and social development is a complex, multi-layered, emerging phenomenon that requires time and skilled leadership and policy approaches to maximize the benefits of local university-industry interactions [30]. Universities contribute to innovation and entrepreneurship through teaching, strategic direction and governance structures. Colleges and universities serving the regions provide fiscal, physical and human resources to create entrepreneurial systems to drive economic development. There are a large number of empirical studies linking regional economic development with higher education, many of which focus on the spending effects of universities. Evidence of the link between economic development and knowledge production by universities is found through two important approaches. The first approach takes universities as the primary factor, with several other factors explaining the concentration of high-tech activities. Second, higher education's 
contribution to the integral development of individuals is to bring together active citizens, participate in peaceful protests and challenge the status quo, build a healthy and just society, promote universal moral values, contribute to developing an individual understanding of oneself and the world around them, and develop students' environmentally friendly worldviews [31]. The development of students' general skills is seen as important and instrumental to the broader logic of human development. This is due to the fact that the terms "university" and "higher education" as search terms are used interchangeably and often treated as interchangeable in literature.

In addition, higher education institutions use various strategies to improve the quality of teaching and provision, believing that the instrumental function of higher education is to create employment. The majority of our respondents argued that the provision of high-quality higher education should be understood as targeting the national labour market and that universities should address global and national challenges. Overall, the above findings are consistent with the literature on links between research universities and nearby high-tech companies. This is evidence of the knowledge effects of colleges and universities. In a later scenario, in which the industrial mix serves as an intermediary between college and university and the development of the regional economy, these institutions could contribute to the county's long-term growth by shifting local activities to growing industries.

\section{Tertiary education institutions and the productive capacity}

The shortcomings of the current scientific method of studying educational productivity mean that much of the available knowledge is considered timid and contingent. There is no universally accepted theory for guiding and financing reform efforts, and several theories are incomplete [32].

The evaluation of the effectiveness of alternative education strategies goes beyond the scope of this article. There is evidence that government spending on primary and secondary education improves school performance and increases government per capita income. Median wages for workers of all levels of education have fallen in the recent years, but college wage premiums - the percentage of income growth for those with a Bachelor's degree or higher compared to those with only a high school education - are still above $85 \%$ [33]. OECD research concludes that measures to improve the graduation rates of secondary and tertiary education improve gross domestic product per capita. There is plenty of evidence that children's success at school depends, at least in part, on the interests and aspirations of their peers. The influence of peers is greater than school effects, including teacher quality [34].

There is also a strong link between education and productivity and economic growth. Universities and other institutions provide not only higher education and continuing education, but also a busy research environment that generates innovation with valuable commercial applications. For the first time in decades, there is evidence of the role of tertiary education, and a report by the Centre for Education and International Development at University College London concludes that it contributes to and improves the quality of life of those who participate and affects their graduates [35].

All in all, tertiary education makes a positive contribution to economic and non-economic development in various ways. Estimates abound that tertiary education contributes to economic development, as it supports the country's economic growth and leads to higher incomes for individual graduates. Tertiary education is crucial to improving primary and secondary education, as tertiary institutions prepare teachers, administrators, executives, and other education professionals to create policies and personnel schools for young children. The skills acquired and improved through higher education contribute to increasing the productivity of the workforce and play an important role in developing the professional skills of those in the country of study. Public and private providers must be able to fulfil the 
comprehensive functions and requirements of the tertiary education sector outlined in this section. To achieve these goals, governance, management, and strategic leadership must be established in tertiary education, as well as in other areas of public management. For example, the stakeholders must ensure that appropriate laws and funding mechanisms are in place and that its role is complemented by institutional stakeholders (public and private), buffer points (regulatory and quality assurance agencies, think tanks, data warehouses) and key actors (represented by the rectors' councils, student organisations, chambers of commerce and industry associations). Increasing public support for formal education, including but not limited to higher education. Public support means making higher education more affordable so that people do not drown in debt after graduation, expanding and improving training infrastructure so that those who do not go to university can enjoy a rewarding, family-sustaining career. These results depend on high-quality and accessible onthe-job training. Increased access to quality education not only increases economic opportunities for residents, but also contributes more to strengthening the overall economy and state government. Governments can enhance the strength of their economies and grow their ability by attracting high-wage employers, investing in education and increasing the number of educated workers. Tax cuts to attract private investment from other states in the race for the bottom of the government's economic development strategy undermine the ability to invest in education. Countries where a larger proportion of their population attends graduate schools have higher economic growth than countries with a less educated workforce. Countries that do not have an extensive network of colleges and universities also benefit from education, and countries that offer basic literacy programs are seeing economic improvements. Raising education levels is an important way to increase productivity and enable income growth that leads to a higher standard of living. Improved access to further education will enable more children to achieve upward mobility, contribute to their full potential and strengthen our overall economy. Understanding how education and training interact with the economy can help explain why some workers and businesses thrive in the economy while others falter. For example, higher levels of education are associated with technological advances and higher levels of entrepreneurial development, which are important sources of job productivity growth. Industries with higher education and training requirements tend to pay workers higher wages. These higher wages may be due to a reduced labour supply that can operate in these sectors, or the necessary training or education may entail significant costs. An oversupply of labour can be harmful for workers working in sectors with low barriers to entry, or for new workers in occupations that do not require a degree or specialised training. We show that the ratio between GDP per capita and universities is not determined by the direct expenditure of the university and its staff and students. Financial problems at the state level have led to funding cuts in public education, reduced education levels, and hampered the future workforce and economic growth that public education generates.

\section{Conclusions and implications}

There are many issues with the determinants of the regional concentration of higher education. For example, sticker price for tuition for students eligible for financial assistance is usually lowered when their account balance is near zero, discouraging them from applying. Governments and policy-makers have to find ways how to channel productive resources to historically lower-class colleges and universities to improve racial equity in access to higher education and to integrate those left behind in geographical regions into the knowledge economy. Nevertheless, evidence from many studies around the world show positive spillover effects of universities on local and regional economies. It turns out that the expansion 
of higher education during this period was not only a product of wealth, but also helped to stimulate economic growth around the world.

Proving the link at country level is difficult because there are many factors that we need to control. The first is the effect of levelling regional performance on a nation's overall economic growth. At the subnational level, if the ignored country-specific factors are kept constant, human capital (as measured by school years) is more important for cross-sectional growth than regional GDP per capita.

In summary, successful regional concentration of higher education brings immediate benefits to spending in the local economy, making a region a more attractive location for people and businesses, and generating long-term benefits from increased human capital, socio-economic feedback, and spill-over effects. This is not to mention that the human capital effect and the location effect are zero-sum games in which one region's success drains other resources. The relation between higher education institutions and local population and employment growth is therefore positive and needs to be fostered and promoted as very beneficial at all levels - both at the private sector level and at the governmental and public levels.

Acknowledgements: This contribution was supported by the Grant No. VEGA 1/0320/21 „Úloha univerzít pri budovaní znalostnej ekonomiky“.

\section{References}

1. J. Bachtler, I. Begg, Papers in Regional Science, 97(1), 151-170 (2018)

2. R. Nureev, V. Volchik, W. Strielkowski, Social Sciences, 9(5), 7 (2020)

3. D. Detter, S. Fölster, The public wealth of cities: How to unlock hidden assets to boost growth and prosperity (2017)

4. E. Hazelkorn, Policy Reviews in Higher Education, 2(1), 4-31 (2018)

5. L. Kempton, European Planning Studies, 27(11), 2248-2265 (2019)

6. S. Mattavarat, P. Viseshsiri, P. Siribanpitak, Kasetsart Journal of Social Sciences, 38(2), 105-110 (2017)

7. M. Scanlon, H. Jenkinson, P. Leahy, F. Powell, O. Byrne, Irish Educational Studies, 38(3), 343-357 (2019)

8. G. Dyer, M. Dyer, Journal of Cleaner Production, 140, 111-116 (2017)

9. V. Scuotto, M. Del Giudice, A. Garcia-Perez, B. Orlando, F. Ciampi, The Journal of Technology Transfer, 45(6), 1634-1654 (2020)

10. W. Strielkowski, V. Volchik, A. Maskaev, P. Savko, Economies, 8(2), 27 (2020)

11. E. Gulicheva, M. Osipova Czech Journal of Social Sciences, Business and Economics, 6(1), 21-27 (2017)

12. E. Glaeser, N. Hausman, Innovation Policy and the Economy, 20(1), 233-299 (2020)

13. T. Agasisti, C. Barra, R. Zotti, Journal of Regional Science, 59(5), 819-849 (2019)

14. X. Hu, Higher Education in Review, 1, 1-12 (2017)

15. N. Neem, Democracy's Schools: The Rise of Public Education in America (2017)

16. V. Žofčinová, M. Barinková, Z. Hrabovská, Public Administration Issues, 6, 133-155 (2020)

17. W. Strielkowski, Y. Tumanyan, S. Kalyugina, Economics and Sociology, 9(2), 293-302 (2016)

18. S. Heaton, D. Siegel, D. Teece, Industrial and Corporate Change, 28(4), 921-939 (2019) 
19. J. Pique, J. Berbegal-Mirabent, H. Etzkowitz, Triple Helix, 5(1), 1-21(2018)

20. A. Valero, J. Van Reenen, Economics of Education Review, 68, 53-67 (2019)

21. D. Cantoni, N. Yuchtman, The Quarterly Journal of Economics, 129(2), 823-887 (2014)

22. Z. Horváthová, A. Čajková, Integration of Education, 22(3), 412-425 (2018)

23. B. Jongbloed, J. Enders, C. Salerno, Higher Education, 56(3), 303-324 (2008)

24. J. Goddard, J. Puukka, Higher education management and policy, 20(2), 11-41 (2008)

25. R. Capello, A. Caragliu, P. Nijkamp, Tijdschrift voor economische en sociale geografie, 102(4), 385-405 (2011)

26. A. Valero, https://cep.lse.ac.uk/pubs/download/dp1764.pdf(2021)

27. M. Benner, European Planning Studies, 27(9), 1791-1810 (2019)

28. M. Rivera, K. Knickel, I. De los Rios, A. Ashkenazy, D. Pears, T. Chebach, S. Šūmane, Journal of Rural Studies, 59, 242-251 (2018)

29. E. Reynolds, Y. Uygun, Technological Forecasting and Social Change, 136, 178-191 (2018)

30. V. Galan-Muros, T. Davey, The Journal of Technology Transfer, 44(4), 1311-1346 (2019)

31. M. Sánchez-Barrioluengo, P. Benneworth, Technological Forecasting and Social Change, 141, 206-218 (2019)

32. G. Guthrie, Classroom change in developing countries: From progressive cage to formalistic frame (2018)

33. T. Bartik, B. Hershbein, https://papers.ssrn.com/sol3/papers.cfm?abstract_id=3141213 (2018)

34. T. Diette, D. Hamilton, A. Goldsmith, W. Darity, RSF: The Russell Sage Foundation Journal of the Social Sciences, 7(1), 166-186 (2021)

35. UCL, https://www.ucl.ac.uk/ioe/departments-and-centres/centres/centre-educationand-international-development (2021) 